\title{
Assessment of Relapse in Patients with Peritoneal Carcinomatosis after Cytoreductive Surgery and Hyperthermic Intraperitoneal Chemotherapy using F-18-FDG-PET/CT
}

\author{
Rezidivdiagnostik nach zytoreduktiver Chirurgie und hyperthermer \\ intraperitonealer Chemotherapie bei Peritonealkarzinose \\ mittels F-18-FDG-PET/CT
}

Authors

Affiliations
B. Klumpp ${ }^{1}$, N. F. Schwenzer ${ }^{1}$, S. Gatidis ${ }^{1}$, I. Koenigsrainer ${ }^{2}$, A. Koenigsrainer ${ }^{2}$, S. Beckert ${ }^{2}$, M. Mueller ${ }^{3}$, C. D. Claussen', C. Pfannenberg'

Diagnostic and Interventional Radiology, Eberhard-Karls-University Tuebingen

2 General, Visceral and Transplantation Surgery, Eberhard-Karls-University Tuebingen

3 Nuclear Medicine, Eberhard-Karls-University Tuebingen

\section{Key words}

- PET/CT

peritoneal carcinomatosis

- relapse

- HIPEC

- cytoreductive surgery

received $\quad 23.11 .2013$

accepted 2.1.2014

\section{Bibliography}

DOI http://dx.doi.org/ 10.1055/s-0034-1366041 Published online: 2014 Fortschr Röntgenstr 2014; 186: 359-366 @ Georg Thieme Verlag KG Stuttgart · New York ISSN 1438-9029

\section{Correspondence \\ Bernhard Klumpp}

Diagnostic and Interventional Radiology, Eberhard-KarlsUniversity Tuebingen Hoppe-Seyler-Str. 3

72076 Tuebingen

Germany

Tel.: ++49/7071/2987217

Fax: ++ 49/70 71/58 45

bernhard.klumpp@med.uni-

tuebingen.de

License terms

\section{Zusammenfassung \\ $\nabla$}

Ziel: Die zytoreduktive Operation kombiniert mit einer hyperthermen intraperitonealen Chemotherapie (HIPEC) mit kurativer Zielsetzung bei Peritonealkarzinose (PK) findet zunehmend Verbreitung. Nach HIPEC besteht in der Nachsorge die Herausforderung in der Differenzierung zwischen therapieassoziierten Veränderungen und einem Rezidiv. Die Studie untersucht den diagnostischen Wert der F-18-FDG-PET/CT bei Patienten mit Rezidiv einer PK nach HIPEC.

Material und Methoden: 36 Patienten mit einem Rezidiv nach HIPEC wurden an einem Ganzkörper PET/CT-System untersucht (44 Untersuchungen). Die Untersuchung bestand aus einem 3-DF-18-FDG-PET und einem Kontrast angehobenen CT. Die Beurteilung erfolgte durch zwei erfahrene Auswerter bezüglich Vorhandensein und Ausmaßes der PK basierend auf dem Peritonealkarzinose-Index (PCI). Die Ergebnisse wurden mit dem intraoperativen Befund oder dem Verlauf korreliert.

Ergebnisse: Bei 40 von 44 Untersuchungen ergab sich der Verdacht auf ein Rezidiv. Bei 4 Patienten wurde das Rezidiv mittels F-18-FDG PET/CT nicht entdeckt, bei 8 Patienten das Ausmaß erheblich unterschätzt. Die diagnostische Genauigkeit für den Nachweis der PK betrug Patienten basiert $91 \%$, die Sensitivität $91 \%$ und der positive Vorhersagewert $100 \%$. Der mittlere PCI betrug für PET/ CT $11,4 \pm 11,9$, für CT $8,4 \pm 10,3$ und intraoperativ 16,6 \pm 15 . Das Ausmaß der PK wurde mittels PET/ CT und noch stärker im CT unterschätzt $(p<0,05)$. Schlussfolgerung: Die diagnostische Wertigkeit der F-18-FDG PET/CT nach zytoreduktiver Chirurgie und HIPEC zum Nachweis eines PK-Rezidives ist gegenüber dem Kontrast angehobenen CT überlegen. Jedoch ist die Quantifizierung der Tumorausdehnung aufgrund posttherapeutischer Veränderungen begrenzt.

\section{Abstract \\ $\nabla$}

Purpose: In patients with peritoneal carcinomatosis (PC), cytoreductive surgery combined with hyperthermic intraperitoneal chemotherapy (HIPEC) is an evolving therapeutic approach with curative intention. The differentiation between posttherapeutic findings after HIPEC and relapse of PC is challenging. We evaluated the diagnostic value of F-18-FDG-PET/CT in patients with relapse of PC after HIPEC.

Materials and Methods: 36 patients with recurring PC after HIPEC were examined on a wholebody PET/CT system (44 examinations). The examination included 3 D F-18-FDG-PET and contrast-enhanced CT. Images were assessed by two experienced readers regarding the presence and the extent of PC using the peritoneal carcinomatosis index (PCI). Imaging results were correlated with surgical findings or follow-up.

Results: Relapse was suspected in 40 of 44 examinations. Relapse was missed by F-18-FDG PET/CT in 4 patients and significantly underestimated in 8 patients. The diagnostic accuracy for the detection of PC on a patient basis was $91 \%$, the sensitivity was $91 \%$ and the positive predictive value was $100 \%$. The mean PCI was $11.4 \pm 11.9$ for PET/CT, $8.4 \pm 10.3$ for CT and $16.6 \pm 15.0$ in the case of surgical exploration. The extent of PC was underestimated by PET/CT and even more by CT alone $(\mathrm{p}<0.05)$. Conclusion: The diagnostic value of F-18-FDG PET/CT after cytoreductive surgery and HIPEC in the detection of recurring $\mathrm{PC}$ is superior to contrast-enhanced CT. However, the quantification of the extent of PC is limited due to post-therapeutic tissue alterations.

Key Points:

- Imaging of recurrent PC after HIPEC is challenging due to posttherapeutic tissue alterations.

- The extent of recurrent PC after HIPEC is systematically underestimated by F-18-FDG PET/ CT. 
Kernaussagen:

- Posttherapeutische Veränderungen nach HIPEC stellen eine Herausforderung für die Bildgebung von PK-Rezidiven nach HIPEC dar.

- Das Ausmaß von PK-Rezidiven nach HIPEC wird mittels F-18FDG PET/CT systematisch unterschätzt.

- Im Vergleich zur Kontrast angehobenen CT weist die F-18-FDG PET/CT eine verbesserte Sensitivität für Rezidivmanifestationen einer PK auf.

- Die Übereinstimmung hinsichtlich der Tumorausdehnung zwischen F-18-FDG PET/CT und chirurgischer Exploration ist besser als die zwischen Kontrast angehobener $\mathrm{CT}$ und chirurgischer Exploration.
- F-18-FDG PET/CT provides improved sensitivity for recurrent PC compared to contrast-enhanced CT.

- The correlation of the extent of recurrent PC depicted by F-18FDG PET/CT and surgical exploration is better than that of contrast-enhanced CT and surgical exploration.

Citation Format:

- Klumpp B, Schwenzer N F, Gatidis S et al. Assessment of Relapse in Patients with Peritoneal Carcinomatosis after Cytoreductive Surgery and Hyperthermic Intraperitoneal Chemotherapy using F-18-FDG-PET/CT. Fortschr Röntgenstr 2014; 186: 359-366

\section{Introduction}

$\nabla$

The prognosis for patients with peritoneal carcinomatosis (PC) is usually considered poor [1-3]. Recent developments in patient treatment include total peritonectomy and multivisceral resection of all involved tissue combined with hyperthermic intraperitoneal chemotherapy (HIPEC) as an approach with curative intention [4-6]. Several imaging modalities are used in the preoperative assessment of tumor extent including ultrasound [7], computed tomography (CT) $[8,9]$, magnetic resonance imaging (MRI) [10, 11] as well as F-18-FDG positron emission tomography/computed tomography (PET/CT) $[9,12,13]$. Recent studies indicate good results especially for MRI and PET/CT due to its potential of functional and morphological tissue characterization $[10,11]$. The assessment of recurring PC after HIPEC is even more challenging than the preoperative evaluation as peritonectomy and HIPEC come along with extensive postoperative tissue alterations often accompanied by inflammatory reaction after HIPEC. Thus, imaging modalities relying solely on the morphologic evaluation of the peritoneal cavity may miss either the relapse of PC or mistake postoperative tissue alterations as the relapse of PC after HIPEC [14-16]. The combined functional and morphological approach with F-18-FDG PET/CT seems promising to assess relapse-free survival after HIPEC in patients with PC [12, 15 - 17]. The challenge for PET/CT is that for example inflammatory reaction of the bowel wall after HIPEC is not only reflected by thickening of the bowel wall but also comes along with increased glucose metabolism. On the other hand, recurring PC after HIPEC might be of a different, more micronodular pattern with diffuse spread, which is likely to be significantly underestimated by PET/CT in its extent or might even completely evade detection [18]. However, the accurate assessment of recurring PC is crucial, as patients might benefit from a second HIPEC, if recurring disease is detected at a stage that has not progressed beyond resectability [19]. In this context it is not only of importance to detect PC but also to assess the extent of PC manifestations reliably.

The aim of our study was to assess the diagnostic value of F-18FDG PET/CT in patients with recurring PC after HIPEC in comparison to surgical findings.

\section{Materials and Methods}

$\nabla$

Patient group

36 patients (mean age: $54.7 \pm 12.0$ years) with relapse of PC confirmed by histopathology or follow-up studies after peritonect-

omy and HIPEC were included. Written informed consent was obtained from all patients. Only patients with primary confirmed PC were included. This is a retrospective study based on in-house patient data.

In total, $44 \mathrm{PET} / \mathrm{CT}$ examinations were performed in these $36 \mathrm{pa}-$ tients. 4 patients were examined twice due to a second relapse after resection of the first relapse, 2 patients were examined three times due to a third relapse. Patients underwent surgical evaluation (laparoscopy or laparatomy) if repeated cytoreductive surgery was considered (22 of 44 PET/CT examinations, 19 of 36 patients).

19 patients (22 PET/CT examinations) patients underwent repeated cytoreductive surgery after PET/CT enabling quantitative correlation of surgical and imaging findings on a patient and segmental basis. For the remaining 22 PET/CT examinations, correlation of imaging findings could only be obtained on a patient basis by comparison with biopsy results and/or follow-up studies.

\section{Patient preparation}

Patients fasted for 12 hours before examination. $350 \mathrm{MBq}$ of F18 -FDG were injected intravenously. After injection patients rested during the uptake time to minimize muscular glucose uptake. During the resting/uptake time, $1000 \mathrm{ml}$ of $2.5 \%$ mannitol solution were administered orally to provide intestinal distension to enhance the assessment of the intestinal wall. To reduce misalignment due to intestinal motion, $40 \mathrm{mg}$ of butylscopolaminiumbromide were injected intravenously prior to image acquisition.

\section{Examination protocol}

Patients were examined on a 16/128-slice whole-body PET/CT (Hi-Rez Biograph 16/Biograph mCT, Siemens Health Care, Knoxville TE, USA) (32/12 examinations) consisting of a high-resolution three-dimensional LSO PET and a 16/128 slice multidetector spiral CT with the following technical parameters: peak voltage $120 \mathrm{kV}$, tube current $120-250 \mathrm{~mA}$, rotation time $0.5 \mathrm{~s} / 0.3 \mathrm{~s}$, collimation $0.75 / 1.5 \mathrm{~mm}$ (thorax/abdomen) $/ 0.6 \mathrm{~mm}$, table feed 12 / $24 \mathrm{~mm} / 30.7 \mathrm{~mm}$. Images were acquired monophasically in the portovenous contrast phase after injection of $80-120 \mathrm{ml}$ iopromidium intravenously (370 mg iodine/ml, flow rate $3 \mathrm{ml} / \mathrm{s}$, Ultravist $370^{\circledR}$, Bayer, Leverkusen, Germany) dependent on patient body weight followed by a $40 \mathrm{ml}$ saline chaser. The contrast-enhanced CT images were used for attenuation correction of PET data. PET covered 6-7 beds dependent on patient size with a FoV of $128 \mathrm{~mm} / 400 \mathrm{~mm}$, slice thickness $2 \mathrm{~mm} / 2 \mathrm{~mm}$, resolution $1.78 \times 1.78 \mathrm{~mm} / 0.76 \times 0.76 \mathrm{~mm}, 4 / 2$ iterations and $8 / 21$ subsets, Gauss filter $4 \mathrm{~mm} / 2 \mathrm{~mm}$, algorithm 2D-OSEM/3D-OSEM. The ac- 
quisition time for each bed was $3 \mathrm{~min} / 2 \mathrm{~min}$. PET data were acquired one hour after tracer injection. A dedicated PET-CT workstation (TrueD, Siemens Health Care, Erlangen, Germany) was used for image fusion of PET and CT data and reading. CT images were reconstructed in the transverse plane with a $5-\mathrm{mm}$ slice thickness and a 5-mm increment and the coronal plane with a 3-mm slice thickness and a 2-mm increment.

\section{Image analysis}

Two experienced readers (radiologist and nuclear medicine physician) evaluated PET/CT and contrast-enhanced CT images independently in consensus for the presence and extent of PC using the peritoneal cancer index ( $\mathrm{PCI}$ ) described by Sugarbaker et al. (20): 13 peritoneal segments, lesion size score 0 - 3 for each segment, range of PCI score 0 - 39. These segments cover 9 regions of the peritoneal cavity $(0=$ central, $1=$ right upper abdomen, 2 = epigastrium, 3 = left upper abdomen, $4=$ left flank, 5 = left lower abdomen, $6=$ pelvis, $7=$ right lower abdomen, $8=$ right flank) and 4 intestinal regions ( $9=$ upper jejunum, $10=$ lower jejunum, $11=$ upper ileum, 12 =lower ileum). Tumor manifestations for each segment are characterized by the lesion size score (LS $0=$ no tumor, $L S 1=$ tumor up to $0.5 \mathrm{~cm}$, LS $2=$ tumor up to $5 \mathrm{~cm}$, LS $3=$ tumor exceeding $5 \mathrm{~cm}$ or confluent manifestations). Surgical and histopathological findings were used as the standard of reference for quantitative analysis of imaging results and correlation on a segmental basis (PCI score). If confirmed by histopathology, segments suspected to be involved in PC by PET/CT were classified as correct positive, otherwise as false positive.

\section{Statistics}

Sensitivity, positive predictive value (PPV), and diagnostic accuracy (ACC) were calculated on a patient basis. Negative predictive value and specificity were not applicable as only patients with confirmed relapse of PC were included. To assess the accuracy of PC quantification by PET/CT on a patient basis as well as on a segment basis, PCI scores of PET/CT and contrast-enhanced CT were correlated with intraoperative PCI scores using Spearman's rank correlation coefficient. A Wilcoxon test was used to test for differences in PCI scores. Dedicated software was used for statistical analysis (MedCalc Software, Belgium).

\section{Results \\ $\nabla$}

In total, $44 \mathrm{PET} / \mathrm{CT}$ examinations were performed in 36 patients with recurring PC ( $\boldsymbol{O}$ Fig. $\mathbf{1})$. All 36 patients were examined for the detection of the first relapse of PC after HIPEC. The mean time between HIPEC and diagnosis of relapse (time to relapse: time between initial HIPEC and detection of recurring PC (TTR) given in days) was $341 \pm 269$ days. The mean $\mathrm{PCl}$ as found at the initial peritonectomy/HIPEC was $18.6 \pm 10.8$ ranging between 2 and 39 according to the peritoneal cancer index (PCI) described by Sugarbaker et al. [20]. The initial cytoreduction status post HIPEC was complete prior to $37 \mathrm{PET} / \mathrm{CT}$ and incomplete prior to 7 $\mathrm{PET} / \mathrm{CT}$ ( $\bullet$ Table 1 ). The cytoreduction status (completeness of cytoreduction, CC) was defined according to Sugarbaker et al. [21, 22] as follows: CC 0 : no residual tumor, CC 1 : residual tumor tissue of less than $0.25 \mathrm{~cm}, \mathrm{CC} 2$ : residual tumor $0.25-2.5 \mathrm{~cm}, \mathrm{CC} 3$ : residual tumor $>2.5 \mathrm{~cm}$. CC 0 and 1 were classified as complete cytoreduction, CC 2 and 3 as incomplete cytoreduction. Underlying tumor entities for peritoneal carcinomatosis were colorectal cancer in 13 patients, ovarian cancer in 13 patients, peritoneal

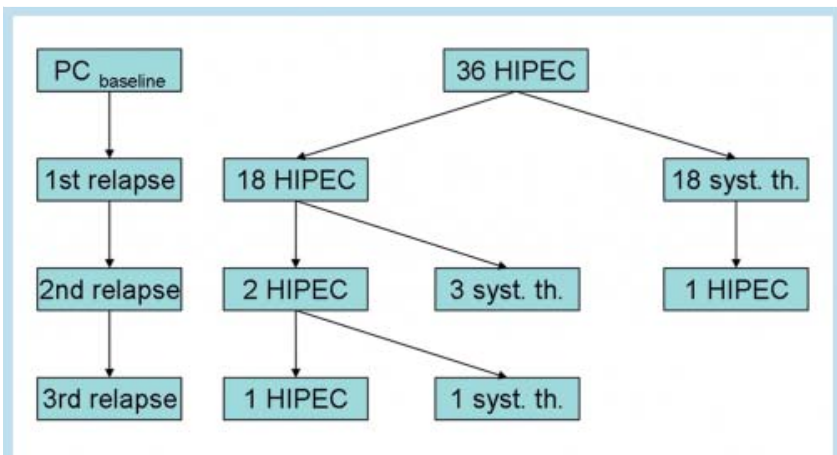

Fig. 136 patients with proven peritoneal carcinomatosis at baseline (PC baseline) and recurrent PC after cytoreductive surgery (HIPEC) were included. At the first relapse, 18 patients were admitted to HIPEC and 18 to systemic therapy (syst. th.). 2 of 18 patients with HIPEC at the first relapse were admitted to repeated HIPEC when PET/CT detected the second relapse, 3 to systemic therapy. 1 of 2 patients treated with HIPEC at the second relapse was admitted to repeated HIPEC when PET/CT detected the third relapse, the other one to systemic therapy. After initial remission, 1 of 18 patients treated with systemic therapy at the first relapse was admitted to HIPEC when PET/CT detected the second relapse.

Abb. 136 Patienten mit nachgewiesener Peritonealkarzinose zu Beginn (PC baseline) und mit Rezidiv nach zytoreduktiver Chirurgie (HIPEC) wurden eingeschlossen. Beim ersten Rezidiv erfolgte bei 18 Patienten eine erneute HIPEC und bei 18 eine systemische Therapie (syst. th.). Bei 2 der 18 Patienten mit HIPEC während des ersten Rezidives erfolgte eine erneute HIPEC nachdem mittels PET/CT ein erneutes Rezidiv diagnostiziert wurde, bei 3 erfolgte eine systemische Therapie. Bei einem der beiden Patienten mit HIPEC während des zweiten Rezidives wurde eine weitere HIPEC durchgeführt, nachdem mittels PET/CT ein drittes Rezidiv diagnostiziert wurde. Bei einem der 18 Patienten, die während des ersten Rezidives mit systemischer Therapie behandelt wurden erfolgte nach initialer Remission eine erneute HIPEC, nachdem mittels PET/CT ein erneutes Rezidiv festgestellt wurde.

Table 1 Patient characteristics.

Tab. 1 Patientendaten.

\begin{tabular}{|lllllll|} 
patients & PET/CT & age & PCI & CC0/1 & CC2/3 & TTR \\
\hline 36 & 44 & $54.7 \pm 12.0$ & $18.6 \pm 10.8$ & 37 & 7 & $341 \pm 269$
\end{tabular}

Table 2 Origin of peritoneal carcinomatosis.

Tab. 2 Ursprung/zugrunde liegende Tumorentitäten der Peritonealkarzinose.

\begin{tabular}{|c|c|c|c|c|c|c|}
\hline $\begin{array}{l}\text { malig- } \\
\text { nancy }\end{array}$ & $\begin{array}{l}\text { colo- } \\
\text { rectal }\end{array}$ & $\begin{array}{l}\text { ovar- } \\
\text { ian }\end{array}$ & $\begin{array}{l}\text { meso- } \\
\text { thelioma }\end{array}$ & ileum & $\begin{array}{l}\text { endo- } \\
\text { metrium }\end{array}$ & appendix \\
\hline patients & 13 & 13 & 3 & 1 & 2 & 4 \\
\hline
\end{tabular}

mesothelioma in 3 patients, ileum cancer in 1 patient, endometrium carcinoma in 2 patients and appendix carcinoma in 4 patients (० Table 2).

Repeated HIPEC was performed in 18 patients at the first relapse. In 2 of the 18 patients with repeated HIPEC, repeated HIPEC was also performed when PET/CT detected a second relapse. 3 patients were treated with systemic therapy at the second relapse. 1 of 2 patients treated with HIPEC at the second relapse also underwent repeated HIPEC when PET/CT detected the third relapse. The other patient was treated with systemic therapy when PET/ CT detected the third relapse ( $\bullet$ Fig. $\mathbf{1}$ ). 
18 patients underwent systemic therapy at the first relapse. The presence of recurring PC in these patients was confirmed by follow up and histopathology.

1 of these 18 patients underwent repeated HIPEC after initial remission when PET/CT detected the second relapse ( $\bullet$ Fig. 1).

In total, 22 repeated HIPEC were performed in 19 patients with recurrent PC ( $\diamond$ Table 4$)$.

Correlating surgical exploration was consequently available for $22 \mathrm{PET} / \mathrm{CT}$ examinations in 19 patients enabling also quantitative assessment of recurrent PC.

In $22 \mathrm{PET} / \mathrm{CT}$ examinations no surgical correlations were possible. For these examinations recurrent PC was confirmed by biopsy in 1 patient, surgically in 5 patients and by follow-up imaging in 16 patients. For those patients with surgically and histopathologically confirmed relapse of PC, no surgical assessment of the PCI was available and therefore no correlation on a segmental basis for quantitative purposes was possible. In those patients with imaging follow-up, new lesions after initial unsuspicious findings were regarded as recurrent PC. In these 22 PET/CT examinations, relapse of PC according to the definition above was confirmed $295 \pm 231$ days after the initial HIPEC.

\section{Detection of PC - patient-based evaluation}

$\nabla$

PET/CT found recurring PC in 40 of 44 examinations. PET/CT missed PC in 4 examinations ( 4 patients) with a surgical PCI of $2-9$ ( $($ Table 3). Imaging findings were interpreted as post-therapeutic tissue alterations and could not be clearly identified as malignant tissue in one patient with regionally increased FDG uptake of the small bowel and moderate thickening of the bowel wall (PCI 9, 76-year-old female patient, PC arising from appendix carcinoma). In one patient a small manifestation was located in the pelvis and in one adjacent to the liver, not detected by PET/CT (PCI 2 in both patients, 60 and 46-year-old female patients, PC arising from ovarian cancer in each). In one further patient, relapse of PC was histopathologically confirmed in spite of negative PET/CT but no cytoreductive surgery was performed (55-yearold female patient, PC arising from ovarian cancer). This patient could not be included in the segmental analysis as no surgical PCI was obtained and was classified false negative. Thus, 4 of 44 PET/CT examinations were classified as false negative. The remaining $40 \mathrm{PET} / \mathrm{CT}$ examinations were rated as correct positive. Based on $44 \mathrm{PET} / \mathrm{CT}$ examinations, the calculated sensitivity was $91 \%$, the positive predictive value was $100 \%$ and the diagnostic accuracy was $91 \%$ for the detection of PC. Negative predictive value and specificity were not applicable.

In 44 examinations in 36 patients, PET/CT suspected PC in 237 of $572(44 \times 13$, mean $5.4 \pm 4.0$, range $0-13)$ peritoneal segments with a mean PCI of $12.6 \pm 10.7$, range $0-39$. The mean PCI in those $22 \mathrm{PET} / \mathrm{CT}$ examinations with surgical correlation was $11.4 \pm 11.9$ and in those $22 \mathrm{PET} / \mathrm{CT}$ examinations without surgical correlation $13.8 \pm 9.5$ which was not found to be a significant difference $(p>0.05)$.

\section{Quantification of PC - segment-based evaluation (PCI) $\nabla$}

19 patients (22 PET/CT examinations) underwent repeated cytoreductive surgery after the PET/CT examination enabling a patient-based and a segment-based correlation of the PCI score. One patient underwent repeated cytoreductive surgery twice,
Table 3 Diagnostic yield of PET/CT.

Tab. 3 Diagnostische Genauigkeit der PET/CT.

\begin{tabular}{|lll|} 
& Positive & Negative \\
\hline Correct & 40 & 0 \\
\hline False & 0 & 4 \\
\hline
\end{tabular}

Table 4 Correlation of the extent of PC depicted by PET/CT (PCI PET/CT relapse), contrast-enhanced $\mathrm{CT}$ ( $\mathrm{PCI} C \mathrm{CT}$ relapse) and results of surgical exploration ( $\mathrm{PCl}$ surgery relapse) in 19 patients subjected to repeated cytoreductive surgery (19 patients, $22 \mathrm{PET} / \mathrm{CT}$ examinations): patient number (column 1), surgically confirmed PCl at the initial HIPEC (PCI baseline, column 2), cytoreduction status after the initial HIPEC (CC baseline, column 3), extent of recurrent PC depicted by PET/CT at the time of relapse (PCI PET/CT relapse, column 4), extent of recurrent PC depicted by contrast-enhanced $C T$ at the time of relapse ( $\mathrm{PCl} C \mathrm{CT}$ relapse, column 5), extent of $\mathrm{PC}$ found by surgical exploration for repeated HIPEC at the time of relapse ( $\mathrm{PCl}$ surgery relapse, column 6) and cytoreduction status after repeated HIPEC (CC, column 7). Patients 8 and 16 underwent a second and third PET/CT and cytoreductive surgery respectively due to second and third relapse of PC ( $\mathbf{F i g .} \mathbf{1})$.

Tab. 4 Korrelation des Ausmaßes der Peritonealkarzinose in der PET/CT ( $\mathrm{PCI}$ PET/CT relapse), Kontrast angehobenes $\mathrm{CT}$ ( $\mathrm{PCI} C \mathrm{CT}$ relapse) und dem intraoperativen Befund ( $\mathrm{PCl}$ surgery) bei 19 Patienten, bei denen eine erneute zytoreduktive Operation durchgeführt wurde (19 Patienten, 22 PET/ CT-Untersuchungen): Patientenzahl (Spalte 1), intraoperativ bestätigter $\mathrm{PCI}$ im Rahmen der initialen HIPEC (PCI baseline, Spalte 2), Resektionsstatus nach der initialen HIPEC (CC baseline, Spalte 3), Ausmaß des Rezidives in der PET/ CT bei Diagnosestellung (PCI PET/CT relapse, Spalte 4), Ausmaß des Rezidives in der kontrastangehobenen CT bei Diagnosestellung (PCICT relapse, Spalte 5), Ausmaß des Rezidives intraoperativ im Rahmen der erneuten HIPEC (PCI surgery relapse, Spalte 6) und Resektionsstatus nach der erneuten HIPEC bei Peritonealkarzinose Rezidiv (CC, Spalte 7). Bei den Patienten Nummer 8 und 16 wurde eine zweite beziehungsweise dritte PET/CT und HIPEC im Rahmen eines zweiten beziehungsweise dritten Rezidives durchgeführt ( $\bullet$ Fig. 1).

\begin{tabular}{|c|c|c|c|c|c|c|}
\hline $\begin{array}{l}\text { patient } \\
\text { number }\end{array}$ & $\begin{array}{l}\mathrm{PCI} \\
\text { baseline }\end{array}$ & $\begin{array}{l}\text { CC } \\
\text { baseline }\end{array}$ & $\begin{array}{l}\mathrm{PCI} \mathrm{PET} / \\
\mathrm{CT} \text { relapse }\end{array}$ & $\begin{array}{l}\mathrm{PCI} C \mathrm{~T} \\
\text { relapse }\end{array}$ & $\begin{array}{l}\mathrm{PCI} \\
\text { surgery } \\
\text { relapse }\end{array}$ & $\begin{array}{l}\text { CC } \\
\text { relapse }\end{array}$ \\
\hline 1 & 17 & 1 & 7 & 11 & 26 & 2 \\
\hline 2 & 11 & 1 & 0 & 0 & 9 & 1 \\
\hline 3 & 14 & 1 & 32 & 9 & 31 & 2 \\
\hline 5 & 15 & 1 & 9 & 5 & 31 & 3 \\
\hline 6 & n. a. & 1 & 10 & 4 & 15 & 3 \\
\hline 7 & 2 & 0 & 2 & 2 & 2 & 0 \\
\hline 8 & 16 & 0 & 2 & 2 & 2 & 0 \\
\hline 8 & 2 & 0 & 24 & 19 & 33 & 3 \\
\hline 9 & 20 & 2 & 8 & 2 & 39 & 3 \\
\hline 10 & 8 & 0 & 6 & 4 & 6 & 0 \\
\hline 11 & 8 & 0 & 0 & 0 & 2 & 0 \\
\hline 12 & 39 & 3 & 39 & 35 & 39 & 3 \\
\hline 14 & 10 & 1 & 8 & 8 & 18 & 1 \\
\hline 16 & 24 & 0 & 2 & 2 & 2 & 0 \\
\hline 16 & 2 & 0 & 2 & 2 & 2 & 0 \\
\hline 16 & 2 & 0 & 14 & 6 & 2 & 0 \\
\hline 19 & 25 & 0 & 13 & 5 & 39 & 3 \\
\hline 20 & 33 & 1 & 39 & 39 & 39 & 3 \\
\hline 22 & 10 & 0 & 0 & 3 & 2 & 0 \\
\hline 23 & 14 & 0 & 12 & 7 & 12 & 3 \\
\hline 31 & 9 & 0 & 8 & 8 & 12 & 3 \\
\hline 32 & 33 & 1 & 14 & 11 & 2 & 0 \\
\hline
\end{tabular}

and one patient three times. In 8 of 19 patients the extent of PC was significantly underestimated by PET/CT being mistaken as 

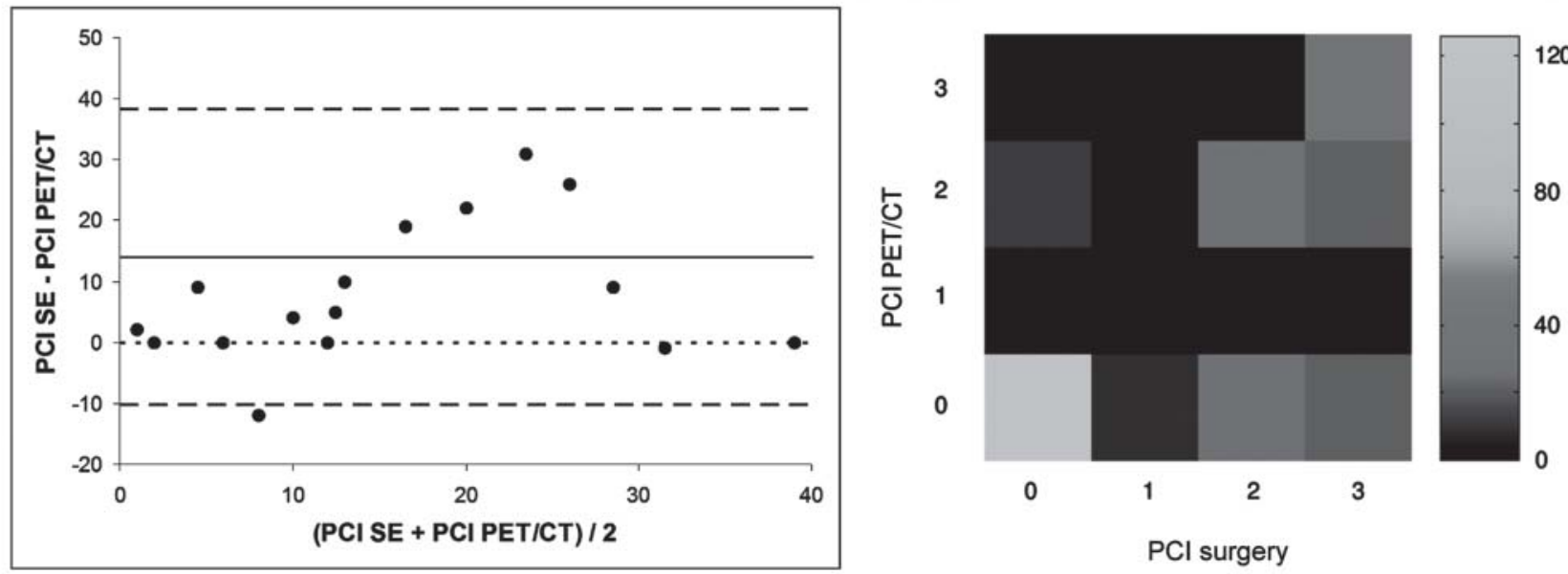

Fig. 2 Bland-Altman plot of the extent of PC given as PCI found by PET/CT (PCI PET/CT) and surgical exploration (PCI surgery): $\mathrm{PET} / \mathrm{CT}$ underestimates $\mathrm{PCl}$ scores consistently (most points are above the zero level); the correlation coefficient is $r=0.64$. Correlation of the extent of $P C$ on a segmental basis (lesion size score 0 - 3 per segment) found by PET/CT (PCI PET/CT) and surgical exploration ( $\mathrm{PCl}$ surgery): The grayscale matrix reflects the number of segments with the respective combination of imaging-based and surgical scores. PET/CT underestimates the $\mathrm{PCl}$ score on a segmental level (most segments are on the lower and right part of the matrix). The correlation coefficient is $r=0.62$.
Abb. 2 Bland-Altman Plot des Ausmaßes der Peritonealkarzinose angegeben als $\mathrm{PCl}$ in der PET/CT (PCI PET/CT) und intraoperativ (PCI surgery): Die PET/CT unterschätzt das Ausmaß der Peritonealkarzinose (Punktverteilung mehrheitlich oberhalb der Nulllinie). Der Korrelationskoeffizient beträgt 0,64 . Korrelation des Ausmaßes der Peritonealkarzinose auf Segmentbasis (lesion size score 0 - 3 pro Segment) in der PET(CT (PCI PET/CT) und intraoperativ ( $\mathrm{PCl}$ surgery): Die Graustufen Matrix zeigt die Anzahl der Segmente mit der zugehörigen Korrelation von PCI-Werten in der Bildgebung und intraoperativ. Die PET/CT unterschätzt den PCI auf Segmentebene (die meisten Segmente befinden sich im unteren rechten Anteil der Matrix). Der Korrelationskoeffizient beträgt 0,62 . resectable PC instead of extended irresectable PC. In one patient, PC was significantly overestimated due to inflammatory tissue alterations.

These 19 patients subjected to repeated cytoreductive surgery were found surgically to have a PCI of $16.6 \pm 15.0$, range $2-39$. On preoperative PET/CT, PCI was rated $11.4 \pm 11.9$, range $0-39$. The mean PCI on contrast-enhanced CT alone was $8.4 \pm 10.3$, range 0 - 39. The mean PCI score per segment was $0.88 \pm 1.2$ for PET/CT, $0.64 \pm 1.1$ for contrast-enhanced CT alone and $1.28 \pm 1.32$ for surgical exploration. The PCI depicted by PET/CT was systematically and significantly lower in comparison to surgical results both on a patient and a segment basis $(\mathrm{p}<0.05)$. Compared to $\mathrm{PET} / \mathrm{CT}$, the PCI assessed on contrast-enhanced CT was significantly lower on a patient basis and on a segment basis as well $(\mathrm{p}<0.05)$.

- Fig. 2 shows the Bland-Altman plot of PCI scores found in PET/ CT compared to surgical PCI scores. Moderate correlations could be observed between imaging-based and intraoperative $\mathrm{PCI}$ scores for PET/CT on a patient base $(r=0.641)$ and on a segment base $(r=0.624)$ as well as contrast-enhanced CT on a patient base $(r=0.553)$ and on a segment base $(r=0.510)$. The comparison of the correlation coefficients indicates a significantly better correlation of PET/CT and surgical findings compared to contrastenhanced CT and surgical findings ( $\mathrm{p}<0.05$ ).

The extent of PC was systematically underestimated by PET/CT and even more by contrast-enhanced CT alone. Patient 32 underwent chemotherapy between PET/CT and surgical exploration explaining the difference in the extent of PC (PCI PET/CT: 14, surgical PCI: 2). In patient 16 , PC was significantly overestimated in the $3^{\text {rd }} \mathrm{PET} / \mathrm{CT}$ due to metabolically active inflammatory tissue mimicking PC ( $\bullet$ Table 4). PC was missed by PET/CT in patients 2, 11 and 22 ( Table 4). In patient 30 relapse of PC missed by
PET/CT was confirmed by biopsy but no repeated HIPEC was performed ( $\triangle$ Table 4 ). In patient 6 no information about the PCI at the baseline peritonectomy and HIPEC (PCI baseline) was available. Compared to PET/CT, the PCI depicted by contrast-enhanced CT was equal or lower in all patients except for patient 1 . In patient 1 multiple calcified small metastases were visible on CT without significant tracer uptake in PET but masked by background signal on fused PET/CT images resulting in a lower PCI on PET/CT than on contrast-enhanced CT. In several patients the $\mathrm{PCI}$ on contrast-enhanced CT was significantly lower than on PET/ CT as increased FDG uptake along the small bowel representing micronodular spread of peritoneal carcinomatosis had no morphologic equivalent on contrast-enhanced CT images and thus evaded detection by sole morphologic assessment.

The second cytoreductive surgery could achieve complete cytoreduction in 9 of 19 patients (CC $0: 7$, CC $1: 2$ ) and in 1 of 9 patients also at the second and third relapse (each CC 0 ). In one patient with complete cytoreduction after the first relapse, only incomplete cytoreduction could be achieved after the second relapse (CC 3). Complete cytoreduction could not be achieved in 10 patients after the first relapse (CC 2: 2, CC 3: 8) and 1 patient after the second relapse ( $\bullet$ Table 4 ).

\section{Discussion \\ $\nabla$}

HIPEC combined with peritonectomy and multivisceral resection is an emerging surgical approach to achieve ultimately complete cytoreduction in patients with PC. New surgical procedures come along with new challenges for imaging techniques monitoring postsurgical results. Patients undergoing HIPEC will have to be monitored afterwards either for the presence of remaining ma- 

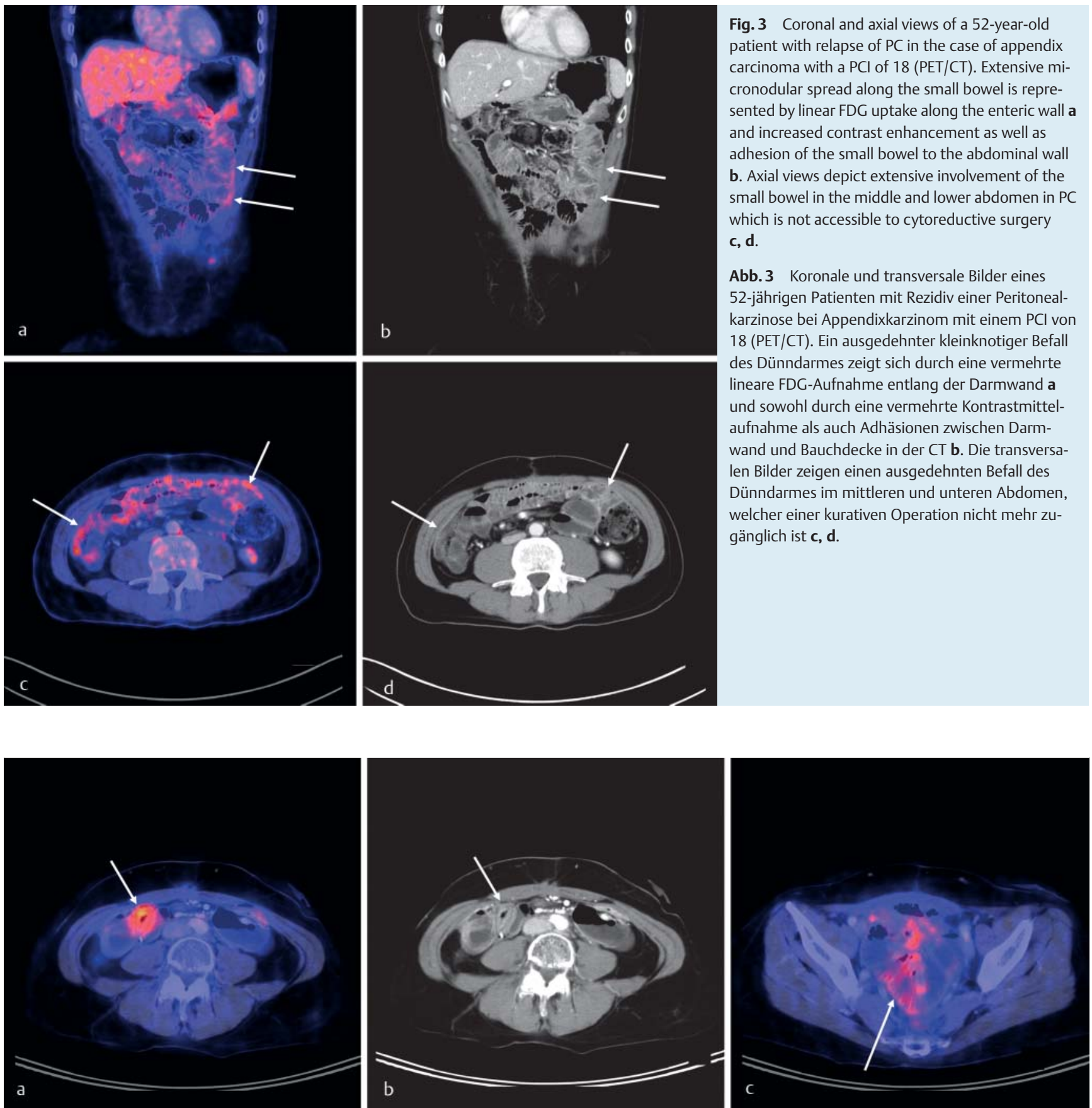

Fig. 4 PET/CT images of a 63-year-old patient with relapse of PC 937 days after peritonectomy and HIPEC reveal tumor-associated stenosis of the small bowel in the middle abdomen on the right side. Characteristics are thickening of the enteric wall $\mathbf{b}$ and markedly increased segmental FDG uptake $\mathbf{a}$. In the pelvis there is also micronodular spread along the small bowel represented by regionally increased FDG uptake $\mathbf{c}$. PCI on PET/CT images was rated 10 , surgically $P C$ was found to be significantly underestimated by PET/CT and beyond resectability due to extensive small bowel involvement.

lignant tissue in the case of incomplete cytoreduction or to detect potential relapse of PC $[23,24]$. In the case of recurring disease early detection of relapse is desirable to provide the opportunity of complete cytoreduction by a repeated HIPEC. The extent of the remaining tumor is the major prognostic factor and complete cytoreduction should be sought above all [25 - 27]. Monitoring dis-
Fig. 3 Coronal and axial views of a 52-year-old patient with relapse of $\mathrm{PC}$ in the case of appendix carcinoma with a PCI of 18 (PET/CT). Extensive micronodular spread along the small bowel is represented by linear FDG uptake along the enteric wall a and increased contrast enhancement as well as adhesion of the small bowel to the abdominal wall b. Axial views depict extensive involvement of the small bowel in the middle and lower abdomen in PC which is not accessible to cytoreductive surgery c, d.

Abb.3 Koronale und transversale Bilder eines 52-jährigen Patienten mit Rezidiv einer Peritonealkarzinose bei Appendixkarzinom mit einem $\mathrm{PCl}$ von 18 (PET/CT). Ein ausgedehnter kleinknotiger Befall des Dünndarmes zeigt sich durch eine vermehrte lineare FDG-Aufnahme entlang der Darmwand a und sowohl durch eine vermehrte Kontrastmittelaufnahme als auch Adhäsionen zwischen Darmwand und Bauchdecke in der CT b. Die transversalen Bilder zeigen einen ausgedehnten Befall des Dünndarmes im mittleren und unteren Abdomen, welcher einer kurativen Operation nicht mehr zugänglich ist c, d.
Abb.4 PET/CT-Bilder einer 63-jährigen Patientin mit PeritonealkarzinoseRezidiv, 937 Tage nach Peritonektomie und HIPEC zeigen eine tumorbedingte Stenose des Dünndarmes im Mittelbauch rechts. Charakteristisch sind eine Darmwandverdickung $\mathbf{b}$ und eine deutlich vermehrte segmentale FDG-Aufnahme a. Im Becken zeigt sich außerdem ein kleinknotiger Befall des Dünndarmes durch flächig erhöhte FDG-Aufnahme c. Der PCI in der PET/CT betrug 10, operativ fand sich jedoch ein nicht mehr resezierbarer Dünndarmbefall, welcher in der präoperativen PET/CT deutlich unterschätzt worden war. 
ate between these postsurgical alterations and remaining or recurring tumor manifestations after HIPEC [29].

Due to the promising results in the preoperative assessment of PC, F-18-FDG PET/CT seems to be an optimal technique to evaluate patients after HIPEC as it is at least comparable if not better than other imaging modalities in the preoperative setting [12]. One aspect in favor of PET/CT is its ability to assess tissue metabolism thus helping to differentiate between malignant tumor and postoperative scar in patients in whom morphologic assessment alone is insufficient [30].

Based on our results, PET/CT seems to perform well also in the follow-up after HIPEC with an overall diagnostic accuracy of $91 \%$ for the detection of PC on a patient basis. However, in four patients the recurring PC was completely missed by PET/CT. In these patients possible signs of PC were discrete and could be explained by postsurgical tissue alterations. Taking into account the additional evaluation of the extent of recurrent PC, PET/CT provided only moderate correlation with surgical findings and systematically underestimated the PCI. Compared to preoperative results, the diagnostic value of PET/CT in the follow-up of patients treated with HIPEC seems to be reduced and is hampered by different factors.

First, in some patients extensive post-therapeutic tissue alterations after HIPEC mask recurring manifestations of $\mathrm{PC}$ in imaging. A second reason to be considered is that the pattern of PC manifestations might vary after HIPEC with a tendency toward a more micronodular pattern accompanied by postsurgical tissue adhesions thus evading detection by PET/CT and other imaging techniques [18]. Manifestations of PC are frequently found in the greater omentum and can be identified there by preoperative imaging as regional enhancement or masses. In the follow-up after HIPEC, the greater omentum is resected and therefore omental masses can no longer be identified. To some extent this effect can also be observed regarding the visceral peritoneum. In preoperative imaging, masses could be found along the bowel on the visceral peritoneum. After peritonectomy, recurring tumor infiltrates the bowel wall which is much more difficult to identify. Moreover, adhesions due to preceding surgery might not only be challenging to differentiate from malignant tissue but also influence the tumor spread. This is supported by a moderate correlation of PC manifestations depicted by PET/CT and found by surgery ( $\bullet$ Fig. 2). Especially the extent of PC was underestimated by $\mathrm{PET} / \mathrm{CT}$ even if the presence could be confirmed reflected by a significant difference in the extent of PC on a segmental basis between PET/CT and surgery ( $\bullet$ Fig. 2 ).

Compared to sole morphologic assessment by contrast-enhanced CT, PET/CT renders superior diagnostic results reflected by significantly higher PCI values and better correlation with surgical findings. Especially intestinal involvement is underestimated by contrast-enhanced CT compared to PET/CT. Increased FDG uptake representing micronodular spread of peritoneal carcinomatosis had at least in parts no morphologic correlate on contrast-enhanced CT images in several patients $\bullet$ Fig. 3. This finding is of importance as extensive small intestine involvement may not be accessible for complete surgical cytoreduction - Fig. 4. Thus, combined morphologic and metabolic assessment provided by PET/CT yields superior diagnostic results compared to morphologic assessment by contrast-enhanced CT.

The combination with other functional imaging modalities including diffusion and perfusion MR imaging as provided by PET/ MRI might result in further improvement of the diagnostic performance in the follow-up after HIPEC $[14,16]$. The combination of PET and dynamic contrast-enhanced MRI might contribute besides metabolic information also information regarding tissue perfusion which might be useful in the differentiation between malignant and inflammatory tissue [11]. Diffusion-weighted magnetic resonance imaging could further enhance tissue characterization in patients with recurrent PC after HIPEC [16]. These options may contribute to further improvement in the follow-up period of patients with PC after HIPEC using PET/MRI to assess recurrent PC.

Limitations of our study include heterogeneous primary tumors which might result in different patterns of tumor spread and tendency of recurrence as well as differing metabolic characteristics. Moreover, the effect of preceding or overlapping therapies might influence results of imaging as FDG uptake might be reduced due to decreasing tumor viability. As only patients with proven recurrence of PC were assessed retrospectively, the statistical power of the results may be restricted due to the lack of true negative patients. To eliminate the resulting statistical bias and provide information regarding true negative patients, specificity and negative predictive value will necessitate periodic relaparotomy or at least laparoscopy in all patients after HIPEC to provide a valid standard of reference for PET/CT in the follow-up period which was not done in our study. Also the fact that recurrent PC was known in all patients might result in a bias as uncertain imaging findings might be more likely to be interpreted as tumor manifestations.

In conclusion, the overall diagnostic value of PET/CT in the detection and evaluation of recurrent PC is superior to contrast-enhanced CT although the extent of PC is underestimated compared to surgical findings. The quantitative assessment of tumor load is limited as reflected by the only moderate correlation with surgical findings. The reasons are extensive post-therapeutic tissue alterations and changes in the pattern of tumor spread after HIPEC which reduce the performance of PET/CT in detecting malignant lesions.

\section{Acknowledgement \\ $\nabla$}

The authors dedicate this article to Prof. Dr. Claus D. Claussen in occasion of his retirement.

\section{References}

1 Al-Shammaa HAH, Li Y, Yonemura Y. Current status and future strategies of cytoreductive surgery plus intraperitoneal hyperthermic chemotherapy for peritoneal carcinomatosis. World J Gastroenterol 2008; 14: 1159 - 1166

2 Sadeghi B, Arvieux C, Glehen $O$ et al. Peritoneal carcinomatosis from non-gynecologic malignancies: Results of the EVOCAPE 1 multicentric prospective study. Cancer 2000; 88: 358 - 363

3 Pyrhoenen S, Kuitunen T, Nyandoto P et al. Randomized comparison of fluorouracil, epidoxorubicin and methotrexate (FEMTX) plus supportive care with supportive care allone in patients with non-resectable gastric cancer. Br J Cancer 1995; 71: 587-591

4 Glehen 0 , Gilly FN, Boutitie F et al. Toward curative treatment of peritoneal carcinomatosis from nonovarian origin by cytoreductive surgery combined with perioperative intraperitoneal chemotherapy. A multiinstitutional study of 1290 patients. Cancer 2010; 116: 5608-5618

5 Raue $W$, Tsilimparis $N$, Langelotz $C$ et al. Initial results after implementation of multimodal treatment for peritoneal malignancies. Acta Chir Belg 2011; 111: 68 - 72

6 Yang XJ, Huang CQ, Suo T et al. Cytoreductive Surgery and Hyperthermic Intraperitoneal Chemotherapy Improves Survival of Patients with Peritoneal Carcinomatosis from Gastric Cancer: Final Results of a Phase III Randomized Clinical Trial. Ann Surg Oncol 2011; 18: 1575 - 1581 
7 Testa A, Ludovisi M, Mascilini F et al. Ultrasound evaluation of intra-abdominal sites of disease to predict the likelihood of suboptimal cytoreduction in advanced ovarian cancer: a prospective study. Ultrasound Obstet Gynecol 2012; 39: 99-105

8 Forstner $R$. Radiological staging of ovarian cancer: imaging findings and contribution of CT and MRI. Eur Radiol 2007; 17: 3223-3246

9 Funicelli $L$, Travaini $L L$, Landoni $F$ et al. Peritoneal carcinomatosis from ovarian cancer: the role of $\mathrm{CT}$ and $\left[{ }^{18} \mathrm{~F}\right] \mathrm{FDG}-\mathrm{PET} / \mathrm{CT}$. Abdom Imaging 2010; 35: $701-707$

10 Low RN, Barone RM, Lacey C et al. Peritoneal tumor: MR imaging with dilute oral barium and intravenous gadolinium containing contrast agents compared with unenhanced MR imaging and CT. Radiology 1997; 204: $513-520$

11 Klumpp BD, Aschoff $P$, Schwenzer $N$ et al. Peritoneal carcinomatosis: comparison of dynamic contrast-enhanced magnetic resonance imaging with surgical and histopathologic findings. Abdom Imaging 2012; 37: 834-842

12 Klumpp BD, Schwenzer N, Aschoff P et al. Preoperative assessment of peritoenal carcinomatosis: intraindividual comparison of F-18-FDG PET/CT and MRI. Abdom Imaging 2013; 38: $64-71$

13 Pfannenberg C, Koenigsrainer I, Aschoff P et al. (18) F-FDG-PET/CT to select patients with peritoneal carcinomatosis for cytoreductive surgery and hyperthermic intraperitoneal chemotherapy. Ann Surg Oncol 2009; 16: $1295-1303$

14 Iafrate $F$, Ciolina $M$, Sammartino $P$ et al. Peritoneal carcinomatosis: imaging with 64-MDCT and 3T MRI with diffusion-weighted imaging. Abdom Imaging 2012; 37: 616-627

15 Priest AN, Gill AB, Kataoka M et al. Dynamic Contrast-Enhanced MRI in Ovarian Cancer: Initial Experience at 3Tesla in Primary and Metastatic Disease. Magn Reson Med 2010; 63: 1044-1049

16 Satoh Y, Ichikawa T, Motosugi $U$ et al. Diagnosis of Peritoneal Dissemination: Comparison of ${ }^{18} \mathrm{~F}-\mathrm{FDG}$ PET/CT, Diffusion-Weighted MRI and Contrast-Enhanced MDCT. Am J Roentgenol 2011; 196: 447-453

17 Glaspy JA, Hawkins R, Hoh CK et al. Use of positron emission tomography in oncology. Oncology 1993; 7: 41-55

18 Forstner $R$, Hricak H, Powell CB et al. Ovarian cancer recurrence: value of MR imaging. Radiology 1995; 196: 715 - 720
19 Dromain C, Leboulleux S, Auperin A et al. Staging of peritoneal carcinomatosis: enhanced CT vs. PET/CT. Abdom Imaging 2008; 33: 87-93

20 Jacquet $P$, Jelinek JS, Steves MA et al. Evaluation of computed tomography in patients with peritoneal carcinomatosis. Cancer 1993; 72: $1631-1636$

21 Jacquet $P$, Sugarbaker $P H$. Current methologies for clinical assessment of patients with peritoneal carcinomatosis. J Exp Clin Cancer Res 1996; 15: 49-58

22 Sugarbaker $\mathrm{PH}$. Cytoreductive surgery and peri-operative intraperitoneal chemotherapy as a curative approach to pseudomyxoma peritonei syndrome. Eur J Surg Oncol 2001; 27: 239-243

23 Bristow RE, Tomacruz RS, Armstrong DK et al. Survival effect of maximal cytoreductive surgery for advanced ovarian carcinoma during the platinum era: a meta-analysis. J Clin Oncol 2002; 20: 1248-1259

24 van der Burg ME, van Lent M, Buyse $M$ et al. The effect of debulking surgery after induction chemotherapy on the prognosis in advanced epithelial ovarian cancer. Gynecological Cancer Cooperative Group of the European Organization for Research and Treatment of Cancer. N Engl J Med 1995; 332: 629-634

25 Du Bois A, Reuss A, Pujade-Lauraine E et al. Role of Surgical Outcome as Prognostic Factor in Advanced Epithelial Ovarian Cancer: A Combined Exploratory Analysis of 3 Prospectively Randomized Phase 3 Multicenter Trials. Cancer 2009; 115: 1234-1244

26 Chi DS, Mc Caughty K, Diaz JP et al. Guidelines and Selection Criteria for Secondary Cytoreductive Surgery in Patients with Recurrent Platinum -Sensitive Epithelial Ovarian Carcinoma. Cancer 2006; 106: 1933 1939

27 Sala E, Kataoka MY, Priest AN et al. Advanced ovarian cancer: multiparametric MR imaging demonstartes response- and metastasisspecific effects. Radiology 2012; 263: 149-159

28 Nougaret S, Addley HC, Colombo PE et al. Ovarian carcinomatosis: how the radiologist can help plan the surgical approach. Radiographics 2012; 32: $1775-1800$

29 Gu P, Pan LL, Wu SQ et al. CA 125, PET alone, PET-CT, CT and MRI in diagnosing recurrent ovarian carcinoma: a systematic review and meta analysis. Eur J Radiol 2009; 71: 164 - 174

30 Berthelot C, Morel O, Girault S et al. Use of FDG-PET/CT for peritoneal carcinomatosis before hyperthermic intraperitoneal chemotherapy. Nucl Med Commun 2011; 32: 23-29 